\title{
Broń drzewcowa z badań podwodnych na reliktach mostu przy słowiańskim osiedlu obronnym w Olsborgu w Plön, na jeziorze Großer Plöner See, w północnych Niemczech
}

Pole Arm from Underwater Excavation on the Relics of a Bridge at the Slavic Defensive Settlement at Olsborg in Plön, on the Großer Plöner See Lake, Northern Germany

Abstrakt: Jezioro Großer Plöner See leży między Kilonią a Lubeką, w centralnej części tzw. Szwajcarii Holsztyńskiej. Wyspowy gród Plune (Olsborg) pojawia się po raz pierwszy w informacji źródłowej kronikarza Adama Bremeńskiego w 1070 r. Przy wyspie grodowej w Olsborgu odkryto I5 grotów włóczni i oszczepów, wydobytych na niewielkiej powierzchni badanego rumowiska mostu. Zespół ten mieści się w świetle badań dendrochronologicznych w przedziale lat od końca $\mathrm{x}$ do końca XI w. Zważywszy jednak na informacje ze źródeł pisanych o niemieckim podboju Wagrii i zniszczenie grodu w latach $1138-1142$, można domniemywać, iż również w tych latach mogły być utracone w rejonie mostu niektóre z odkrytych tam egzemplarzy broni drzewcowej.

Słowa kluczowe: groty włóczni, mosty, wczesne średniowiecze, Großer Plöner See, Północne Niemcy

Jezioro Großer Plöner See i osadnictwo słowiańskie w jego rejonie

Jezioro Großer Plöner See leży między Kilonią a Lubeką, w centralnej części tzw. Szwajcarii Holsztyńskiej, w paśmie moren czołowych ostatniego zlodowacenia bałtyckiego. Stąd dominującym elementem geomorfologicznym bezpośredniego otoczenia jeziora jest pagórkowata wysoczyzna morenowa z licznymi wypiętrzeniami osiągającymi tutaj maksymalną wysokość do $87 \mathrm{~m} \mathrm{n.p.m.,} \mathrm{przy} \mathrm{lustrze}$ wody leżącym na wysokości około 2I m n.p.m., z tolerancją + - o,5 m. Omawiane jezioro, dziesiąte co do wielkości w Niemczech, ma powierzchnię około $29 \mathrm{~km}^{2}$, długość $8,7 \mathrm{~km}$, szerokość 7,2 km i maksymalną głębokość dochodzącą do $58 \mathrm{~m}$. 
Na początku XIII w. jezioro zostało po raz pierwszy sztucznie spiętrzone o prawie $3 \mathrm{~m}$. Miało to bezpośredni związek z budową młynów wodnych na rzece Schwentine. Pierwsze informacje o tego typu inwestycjach pochodzą już z I22 I r. (Dörfler 2009: 154). Budowa młynów i spiętrzenie w wyniku tych inwestycji wód jeziora spowodowały, iż pod jego lustrem znalazły się nie tylko wielkie połacie uprawnej ziemi, łąk i pastwisk, ale i niektóre osiedla lub ich najniżej położone części. Wysoki poziom wody trwał przez przeszło 600 lat. Stopniowa likwidacja młynów wodnych oraz akcje melioracyjne prowadzone w rejonie omawianego jeziora spowodowały, iż lustro wody opadło wtedy o około I,5 m, stabilizując się na dzisiejszym poziomie.

Interesująco rysuje się w rynnie jeziora Großer Plöner See obraz jego zasiedlenia przez Słowian. W rejonie tym znanych jest prawie 30 stanowisk słowiańskich, w tym również pewna ich część w przybrzeżnych partiach wysp i półwyspów pod lustrem wód jeziora (Wilke 1998: 270, ryc. 5). Wśród tych stanowisk egzystowały tutaj również dwa grody usytuowane na wyspie: w Bosau (obecnie na półwyspie Bischofswarder) i znany ze źródeł pisanych gród Plune (Płonia), którego relikty usytuowane są obecnie na wyspie Olsborg, w Plön. Grody te stanowiły centra niewielkich skupisk osadniczych, leżących na terytorium Wagrów, jednego z głównych plemion związku obodryckiego, na północno-zachodnich krańcach ówczesnego świata słowiańskiego. W okresie późnosłowiańskim funkcjonowało tutaj już kilkanaście dalszych grodów, świadczących o intensywnym osadnictwie słowiańskim na tym terenie. Na zachód od tych grodów przebiegał Limes Saxoniae, gdzie Wagrowie graniczyli już bezpośrednio z saskimi Nordalbingami (ryc. I).

Początek osadnictwa słowiańskiego na terytorium Wagrii przypada tu w świetle badań archeologicznych już na pierwszą połowę viII w. W tym czasie powstaje w Bosau osiedle obronne, usytuowane w południowo-wschodniej części jeziora Großer Plöner See, przechodzącego przy grodzie w mniejszy akwen tego jeziora, zwany Bischofssee. Osiedle to funkcjonowało tutaj do drugiej połowy IX w. (Kempke 1992: 154; Bleile 20II: 68). Ostateczny kres kilkusetletniemu osadnictwu słowiańskiemu na terenie Wagrii położył jednak dopiero podbój jej zachodniej części przez Niemców, zakończony w latach II38-II 42 (Kempke 1992: I63).Zniszczeniu ulega wtedy również gród na wyspie Olsborg, w Plön. W tym bowiem czasie, w wyniku nieudanego powstania Słowian pod wodzą księcia obodryckiego Przybysława, władzę w Wagrii obejmuje hrabia Adolf I z Schauenburga, który już w II 43 r. sprowadza tu osadników z Westfalii, Fryzji oraz Holandii i Flandrii. Następny władca Wagrii, hrabia Adolf II, odbudowuje w II56 r. zniszczony wyspowy gród Plune, ale już w 1173 r. przenosi go na przeciwległy brzeg jeziora, na rozległe, wysokie wzgórze morenowe zwane Bischofsberg. U jego stóp powstaje nowe osiedle, które już I239 r. uzyskuje prawa miejskie jako miasto Plön (Müller 20II: 9I). To Adolf II był w tym czasie największym promotorem chrystianizacji 


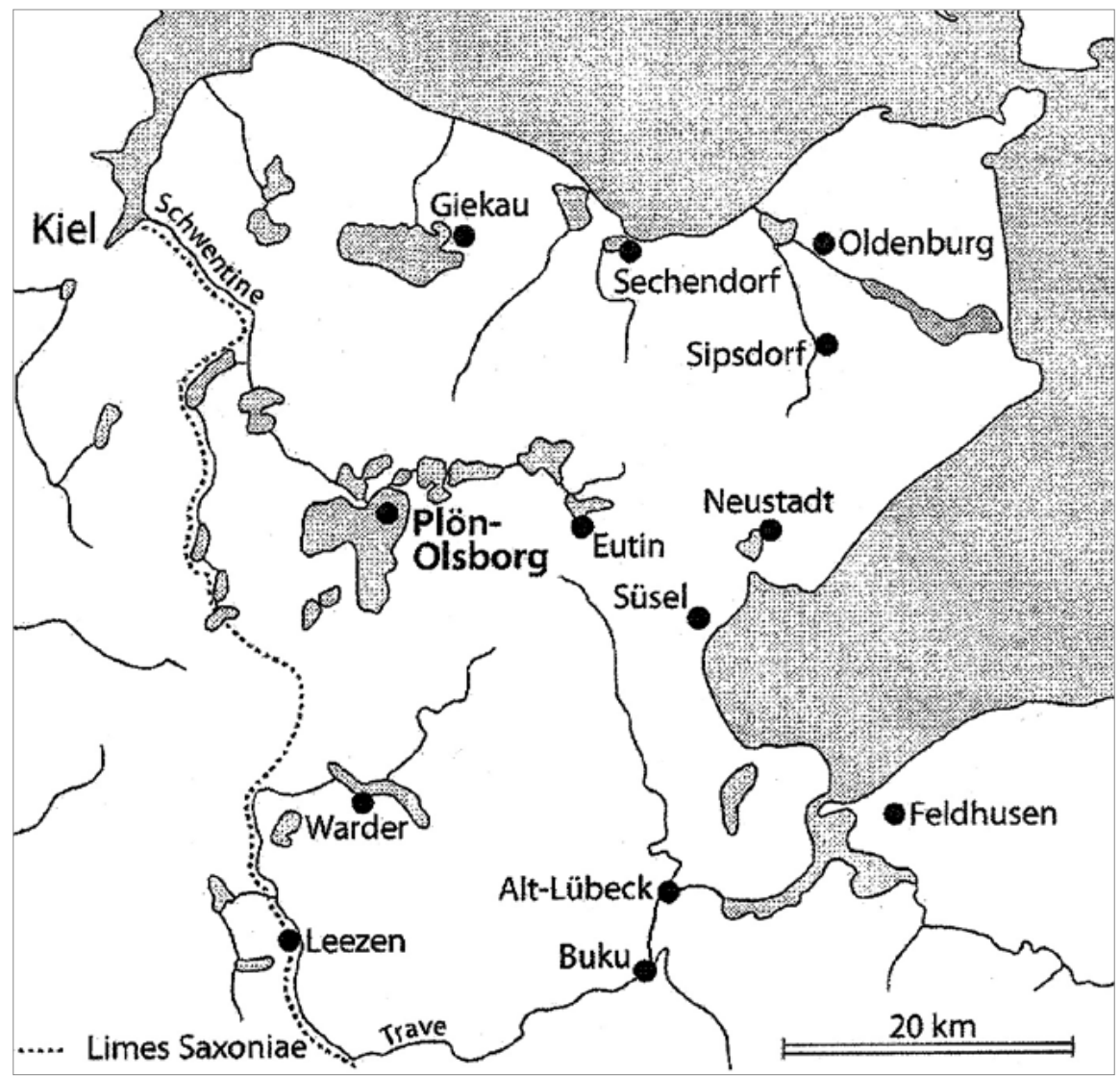

Ryc.1. Gród w Plön-Olsborg na tle późnosłowiańskich grodów na terytorium Wagrii wraz z przebiegiem limesu saksońskiego (wg Wilke 2009: ryc. 2; rys. A. Link).

ziem słowiańskiej Wagrii i dalszej jej niemieckiej kolonizacji. Wzgórze Bischofsberg zostało zajęte później przez monumentalny zamek władców duńskich, górujący do dzisiaj wyniośle nad jeziorem Großer Plöner See, z wyspą grodową Olsborg na pierwszym planie.

\section{Olsborg w świetle źródeł pisanych i archeologicznych}

Wyspowy gród Plune wzmiankowany był po raz pierwszy przez kronikarza Adama Bremeńskiego w ro70 r.... in quo Plunie civitas sita est (Adam von Bremen 13, 74). Później wzmiankowany był kilka razy przez kronikarza Helmolda z Bosau, który od około II56 r. aż do śmierci w I077 r. był proboszczem w tej miejscowości. Z proboszczówki roztaczał się widok na dawną wyspę grodową w tej miejscowości. 
W tym czasie istniał w Bosau już niewielki, rotundowy kościół romański. W historiografii przyjmuje się, iż w latach II63-II68 powstawało pomnikowe dzieło Helmolda Chronica Slavorum, poświęcone jednak nie całej Słowiańszczyźnie, jak mógłby sugerować tytuł kroniki, a tylko jej północno-zachodniej, połabskiej części (Fraesdorf 2005: I58 nn.). Motywem przewodnim jest w tym dziele długotrwały proces chrystianizacji tej części Połabszczyzny, z idącymi nierozerwalnie w parze niemieckimi podbojami militarnymi terytoriów zajętych przez plemiona słowiańskie.

W swym dziele Helmold informuje nas nie tylko o burzliwych losach tego ufortyfikowanego grodu (propugnaclua), zwanego jako castrum Plunense (Helmold, roz. 25, s. 16I), ale również o pewnych elementach topograficznych, m.in. mostu (pons longissimus), który pierwotnie łączył wyspowe osiedle z przeciwległym brzegiem jeziora (Helmold, roz. 25, s. 162). Obok tych informacji prezentuje się Olsborg z miejscem kultowym, poświęconym bogowi Podaga (Helmold, roz. 84, s.330). Odkryty na wyspie, w trakcie badań archeologicznych w latach 2004-2007, ośmiobocznie, bardzo starannie obrobiony słup o przekroju $33 \mathrm{~cm}$, z wielobocznym, tępo zakończonym szpicem, umocowany w niewielkiej jamie fundamentowej kamieniami, jest być może pozostałością słupa dźwigającego podobiznę wspomnianej figury kultowej (Bleile 20ı1: 75). W trakcie tych badań odkryto również relikty domostw półziemiankowych oraz naziemnych, zadokumentowano także śladowo relikty umocnień obronnych. Być może, po podniesieniu lustra wód jeziora na początku XIII w., fale uderzające przez setki lat w brzeg wyspy i napory kry lodowej zniszczyły całkowicie pierwotną linię brzegową i znajdujące się przy niej umocnienia (Bleile 2oır: 68). Warto też wspomnieć o kolejnej podwodnej prospekcji na południe od wyspy. Na wypłyceniu jeziora o długości ca. 300 metrów, przy jego południowo-zachodniej krawędzi, odkryto na głębokości od I do 4 metrów rzędowy, palisadowy układ 80 pali, zadokumentowany na długości prawie $60 \mathrm{~m}$ (Bleile i in. 20I0: 31, ryc. 7.I). Odkrycie to wskazywałoby, iż pierwotnie, przed podniesieniem się lustra wód jeziora, wyspowe osiedle obronne było znacznie większe, a dwa wydatowane pale wskazują, iż odkryta fragmentarycznie palisada funkcjonalnie związana była z najmłodszymi fazami funkcjonowania osiedla.

Relacjonując walki o tron Obodrytów po zamordowaniu księcia Gotszalka, pomiędzy jego dziedzicznym następcą, księciem Budziwojem a księciem Krutem, konkurentem do obodryckiego tronu, wspomina Helmold również kilkakrotnie o interesującym nas moście. Budziwoj, przy pomocy saskich Bardów, zajmuje w roku 1074 lub 1075 opuszczony gród w Olsborgu, który był zasadzką na Budziwoja, uczynioną przez księcia Kruta. Helmold relacjonuje: Jest zaśów gród, jak to jeszcze dziśs można widzieć, zewsząd otoczony bardzo gtębokim jeziorem; dojście doń przychodzacym daje bardzo dtugi most (Helmold, roz. 25, s. I62). Budziwoj oblegany w grodzie z dużym oddziałem zbrojnych znalazł się w trudnej sytuacji nie tylko 


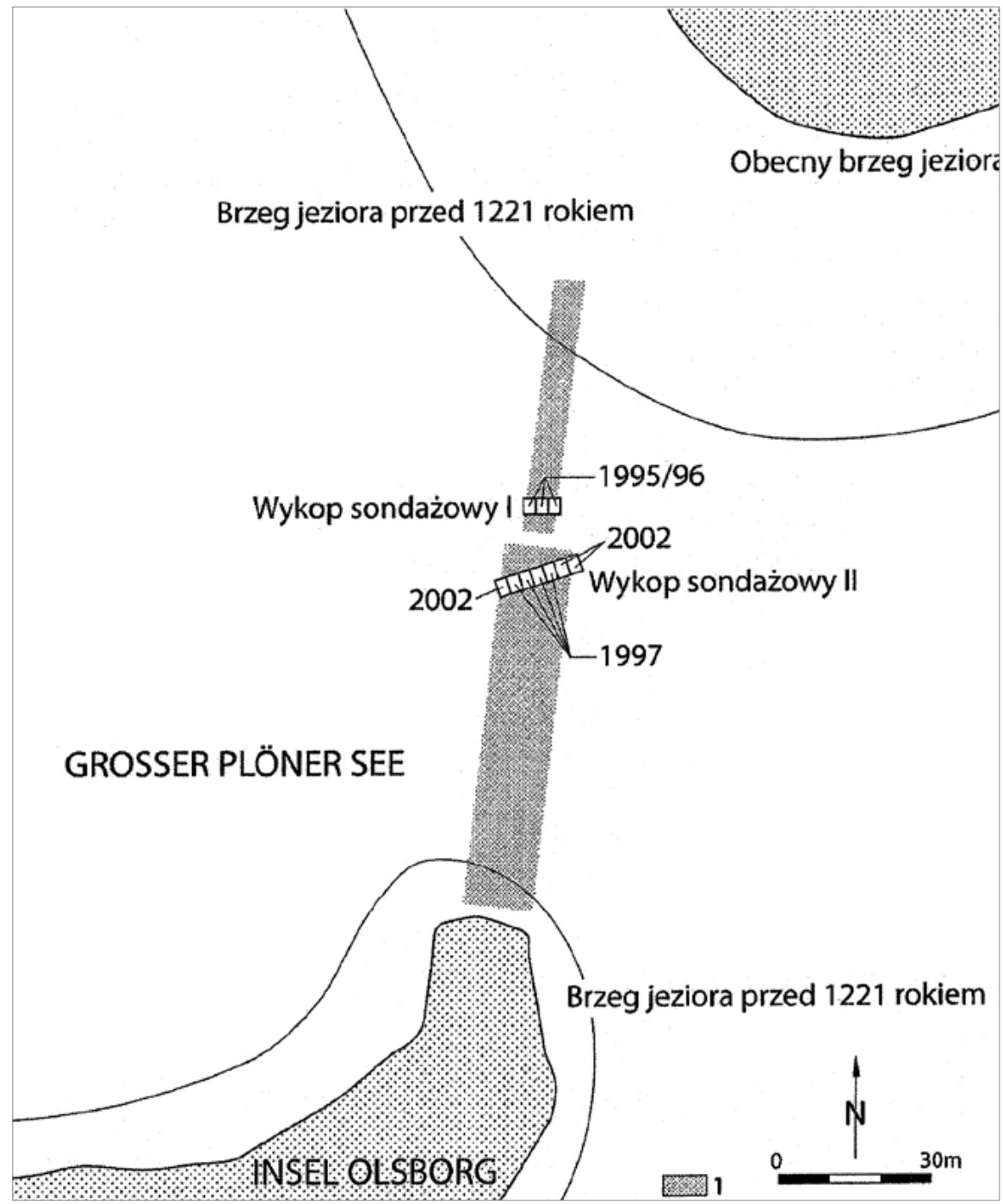

Ryc.2. Plön-Olsborg. Profil jeziora Großer Plöner See między wyspą grodową Olsborg a stałym lądem wraz z poziomami lustra jeziora i usytuowaniem rynny rzeki Schwentine (wg Wilke 2009: ryc.3; rys. A. Link).

militarnej, ale i z powodu doskwierającego im już głodu, jak i braku oczekiwanej pomocy od saskich plemion Nordalbingów. Pertraktacje rozjemcze rozpoczął Krut ...przeszedt przez most [zapewne do bramy grodowej] i rzekt do Budziwoja i jego towarzyszy: „Myśl o ocaleniu swoim i swoich ludzi, którzy sa z toba, poniewaz Sasi, na których liczyteś, tym razem nie przyjdą ci z pomoca" (Helmold, roz. 25, s. 163). 
Jak donosi o tych wydarzeniach Helmold, Sasi pozostawili Budziwoja na łasce losu, tj. Kruta, który zażądał nie tylko opuszczenia grodu, ale i oddania broni. Mimo trudnych warunków poddania, Budziwoj, jak i jego wojowie nie mieli innego sposobu dla ratowania życia, jak wyjście z grodu. Przechodzili potem przez mostpo dwóch, zdajac broń i tak zaprowadzono ich przed oblicze Kruta (Helmold, roz. 26, s. 165). Tu oskarżeni przez jedną z kobiet z grodu o gwałty poczynione na pozostawionych tam wielu kobietach, zostali wszyscy wycięci mieczami przez wojów Kruta. Dzięki temu zwycięstwu Krut zdobył władzę w całej zachodniej części Połabszczyzny, w całym kraju Obodrytów, zmuszając jednocześnie do trybutu plemiona saskie, Holzatów, Szturmarów i Ditmarszów, zamieszkujących Nordalbingię.

Jak długi był Helmoldowy pons longissimus? Dzisiejszy przesmyk między wyspą a stałym lądem wynosi w najwęższym miejscu około 160-170 m. Zważywszy jednak na fakt, iż brzegi wyspy i przeciwległego brzegu z okresu funkcjonowania grodu znajdują się dzisiaj w toni jeziora, przyjąć można, iż most miał pierwotnie długość około I20-130 m (por. ryc. 2).

Kolejna relacja Helmolda o moście wiąże się z walkami księcia Świętopełka z jego bratem Kanutem, który chciał panować sam w księstwie Obodrzyckim. Wydarzenia te miały miejsce przed r. II27. Swiętopełk przywołał do pomocy saskich Holzatów i oblegał go w płońskim grodzie, forsując zapewne w tym celu most, stanowiący doń jedyne dojście. Kanut, nie chcąc bratobójczej walki, siadłszy na blankowaniu grodu, ...zakazat swym towarzyszom rzucać oszczepami do oblegajacych (Helmold, roz. 48, s. 232). Postawa Knuta i pokojowe warunki pojednania sprawity, iż Holzatowie pogodzili braci i dokonali pomiędzy nich dalszego podziału kraju.

Również w kampanii wojennej hrabiego Henryka z lat I138-I139, który przy pomocy saskich wojsk Holzatów i Szturmarów wszedł zimową porą na słowiańskie tereny dzisiejszego, południowo-wschodniego Holsztynu, m.in. ziemi starogardzkiej i płońskiej, jesteśmy konfrontowani z grodem płońskim. Wojska hrabiego dokonały tam ogromnych zniszczeń, biorąc wszędzie łupy wojenne. Najbliższego lata Holzatowie... podsunęli się pod gród Ptonię i dzięki Boskiej pomocy wbrew nadziei opanowali to miejsce, choć byto silniejsze od innych. Stowian zaś, którzy sie tam znajdowali, wycięli w pień (Helmold, roz. 56, s. 256).

Wszystkie te relacje Helmolda o moście prowadzącym do płońskiego grodu i jego miejscu w kampaniach wojennych są pewną wskazówką, iż z tych wypadków mogą pochodzić liczne militaria, głównie groty broni drzewcowej. Zostały one bowiem zadokumentowane $w$ trakcie badań archeologicznych na dnie jeziora na obrzeżach wspomnianego mostu lub bezpośrednio pod jego reliktami, już w rumowisku dennym.

Wśród kilkudziesięciu średniowiecznych mostów, znanych już z archeologicznych badań podwodnych na terenie Polski i Niemiec, znaleziska broni, a szczególnie egzemplarze broni drzewcowej, nie należą do powszechnie odkrywanych, 
zamykając się liczbą pojedynczych lub co najwyżej kilku egzemplarzy (Chudziak i in. 20II; 2016). Na ogół odkrywa się przedmioty codziennego użytku, utracone czy wyrzucone w trakcie przemieszczania się po moście lub w czasie czynności gospodarczych w rejonie mostów. Rzadkość militariów potwierdza niewątpliwie fakt, iż broń otoczona była szczególną troską i ochroną ich użytkowników, a nie przypadkowo tracona. Wyjątkiem są niewątpliwie tylko walki na mostach, prowadzone przy wyspowych osiedlach otwartych i grodach, szczególnie w ich przybramnych partiach, czy też na jeziornych mostach i brodach rzecznych, gdzie te militaria były już bezpowrotnie utracone.

Tylko na czterech rzekach na obszarze Meklemburgii-Przedpomorza, zasiedlonego przez Słowian Połabskich, północnej grupy Wieletów, tj. na Peene, Recknitz, Tollensee i Trebel, zadokumentowano ich ślady pobytu w 387 miejscach, skupiających się na 16I wydzielonych stanowiskach archeologicznych (Anders 2007: 322). W tych miejscach odkryto też dużą liczbę militariów, zamykających się w 289 egzemplarzach, w tym I 40 okazów broni drzewcowej (Anders 2013: 248-252, por. listę znalezisk grotów). Militaria te zostały zapewne utracone w nurtach wspomnianych rzek w różnych warunkach - w czasie transportu wodnego i przybrzeżnej komunikacji między licznymi grodami i osiedlami skupionymi nad tymi rzekami, na przeprawach mostowych i brodach. Duża ich część została jednak niewątpliwe utracona w czasie konfliktów zbrojnych z obcymi agresorami, jak i w czasie walk międzyplemiennych pomiędzy książętami słowiańskimi.

$\mathrm{Na}$ obszarze zasiedlonym przez Wieletów, którzy byli w czasie swej kilkusetletniej historii wielokrotnie atakowani przez wojska władców frankońskich, niemieckich, duńskich i polskich, część tych znalezisk broni jest niewątpliwie niemym śladem tych militarnych działań. Warunki jej utracenia w nurtach rzek powodowały, iż broń ta była trudna do ponownego odzyskania. Warto tu też dodać, iż na wszystkich wspomnianych militariach tylko śladowo spotyka się uszkodzenia, tak że nie ma podstaw, aby te zespoły zabytków traktować jako broń ofiarną wrzuconą do wody w kontekście starych tradycji pogańskich, rytualno-magicznych. W najbardziej znanych pradziejowych, jak i średniowiecznych kolekcjach ofiarnych militariów prawie wszystkie wykazują zniszczenia ich fragmentów lub też całych egzemplarzy. Dla przykładu wymienimy tu tylko najbardziej znane stanowisko tego typu w Gudingsåkrarna na Gotlandii, gdzie wśród prawie 600 militariów odkryto 225 grotów włóczni i oszczepów (Müller-Wille 1999: 77). Intencjonalne, celowe uszkodzenia części tych militariów - pociętych, połamanych, powyginanych i przepalonych w ogniu, jak i sposób deponowania niektórych grotów na dnie badanego dawnego akwenu, świadczą o ofiarnym charakterze tego stanowiska, datowanego na okres między VII a XI w.

O działaniach militarnych związanych z mostami informują nas dość licznie różne kroniki średniowieczne, m.in. Thitmara, relacjonującego potyczki wojenne 
polsko-niemieckie, Galla Anonima, wspominającego kampanie wojenne pierwszych Piastów, Saxo Grammaticusa, opisującego wyprawy duńskie na słowiańskie wybrzeża Morza Bałtyckiego w drugiej połowie XII w., czy Kosmasa z Pragi, relacjonującego kampanię wojenną Bolesława Chrobrego w Czechach, czy wreszcie wspominanego już Helmolda z Bosau, opisującego walki Słowian Połabskich z Niemcami oraz również ich walki pobratymcze (Wilke 2006).

Do takich działań wojennych należy niewątpliwie zaliczyć odkrycie dość dużej kolekcji militariów na reliktach wylądowionego obecnie mostu, o pierwotnej długości $320 \mathrm{~m}$ w Behren-Lübchin, gdzie w rejonie bramy grodowej i spalonego budynku mostowego odkryto m.in. 27 toporów i i grotów włóczni (Schuldt 1965: 64; Wilke 20II: $106 \mathrm{i} \mathrm{nn.).} \mathrm{Militaria} \mathrm{te} \mathrm{znalazły} \mathrm{się} \mathrm{na} \mathrm{dnie} \mathrm{jeziora} \mathrm{prawdopodob-}$ nie w wyniku działań militarnych w czasie oblężenia i zniszczenia grodu przez Waldemara I duńskiego w II7I r. (Schuldt 1965: I27). Do wyjątkowych odkryć na terenie całej Słowiańszczyzny należy niewątpliwie kolekcja militariów, w tym 58 egzemplarzy broni drzewcowej ( 56 grotów włóczni i 2 okucia końca drzewc, tzw. toki), zadokumentowana na reliktach dwóch mostów przy rezydencji pierwszych Piastów na Ostrowie Lednickim (Sankiewicz 2018: 147-215; Wilke 2018: 33-87). Ich zaleganie na dnie jeziora w rejonie wyspowych przyczółków mostowych było zapewne rezultatem walk toczonych o zdobycie królewskiej rezydencji, co miało miejsce w czasie napaści czeskiego księcia Brzetysława na teren Wielkopolski W I038 lub I039 r.

W świetle tych wypadków należy niewątpliwie oceniać również analogiczne znaleziska broni drzewcowej przy wyspie grodowej w Olsborgu. Doszło tutaj do odkrycia liczącego jak dotąd zbioru Is grotów, wydobytego tylko z niewielkiej powierzchni badanego rumowiska mostu, eksplorowanego w niedalekiej odległości od brzegu wyspy.

\section{Warunki i miejsce odkrycia grotów na reliktach mostu w Olsborgu}

Już pierwsze penetracje podwodne prowadzone przez autora w 1995 r. potwierdziły, iż na przesmyku pomiędzy lądem stałym a północnym cyplem wyspy Olsborg znajdują się relikty tego mostu w postaci pali wbitych w dno jeziora, z których tylko niektóre widoczne były jeszcze nieznacznie ponad dnem jeziora. Prace podwodne już o charakterze eksploracyjnym, rozpoczęte w 1995 r., prowadzone były przez Institut für Ur-und Frühgeschichte der Christian Albrechts Universität zu Kiel, pod kierownictwem dr. Gerarda Wilke, w ramach programu badawczego „Unterwasserarchaologie in Ostholstein". Badania te kontynuowane były w latach 1996-1997 i w roku 2002 (Wilke 2005; 2009). We wszystkich tych pracach uczestniczyli również pracownicy, jak i studenci Zakładu Archeologii Podwodnej Uniwersytetu Mikołaja Kopernika w Toruniu, pod kierownictwem prof. dr. hab. Andrzeja Koli. 

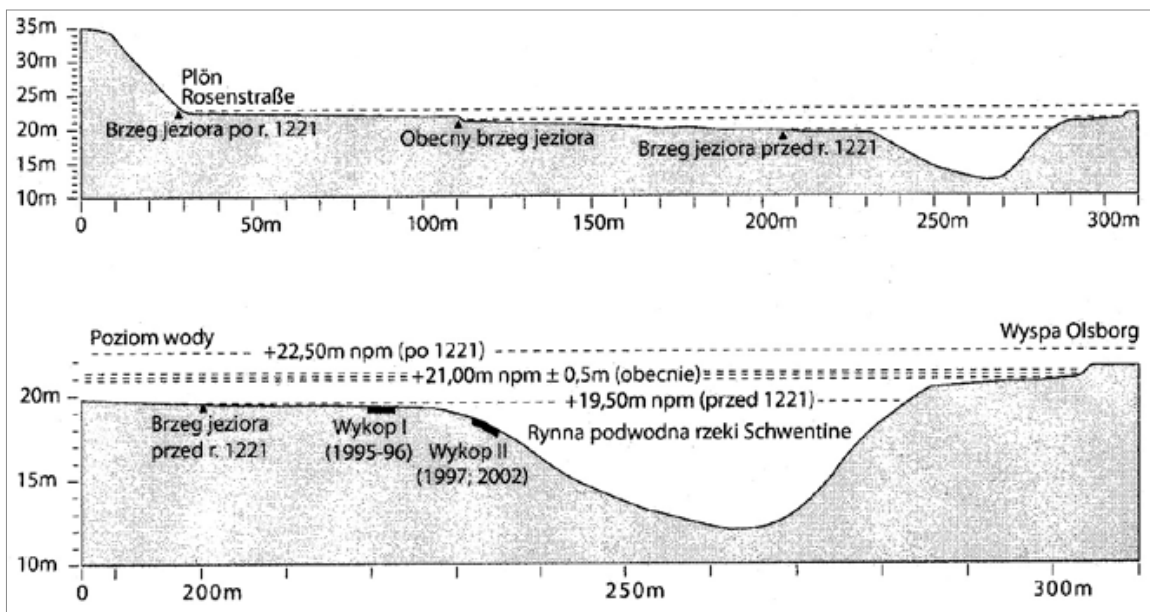

Ryc. 3. Plön-Olsborg. Usytuowanie wykopów na dnie jeziora pomiędzy wyspą Olsborg a brzegiem stałego lądu.

Legenda. I. Relikty odkrytych konstrukcji nośnych mostu wraz z jego przebiegiem (wg Wilke 2009: ryc. 4; rys. A. Link).

Relikty mostu szczególnie dobrze widoczne były na północnym stoku jednego z trzech podwodnych koryt rzeki Schwentine, przepływającej poprzez jezioro Großer Plöner See i kierującej dalej swój bieg do Fiordu Kilońskiego, wyznaczając na ostatnich kilkudziesięciu kilometrach końcowy odcinek limesu saksońskiego (por. ryc. I). Koryto tej rzeki zlokalizowane w niedalekiej odległości od wyspy Olsborg osiąga w tym rejonie szerokość około $50 \mathrm{~m}$ i głębokość do Io m (ryc. 2).

Eksplorację reliktów mostu prowadzono w obrębie dwóch jednostek badawczych, oznaczonych na dnie jeziora ramami, podzielonymi na mniejsze jednostki eksploracyjno-dokumentacyjne o rozmiarach 2,5-3,0 m. Odkrywane pale konstrukcji nośnej mostu znajdowały się na ogół pod kilkunastocentymetrowym namuliskiem dennym. W wykopach nr I, o rozmiarach 7,5 x 3,0 m, odkryto 5 I pali i w nr II, o rozmiarach 17,5 x 3,0 m, odkryto I87 pali, co zamyka się łączną liczbą 238 pali zlokalizowanych na osi mostu (por. ryc. 3). Pale mostowe posiadały średnicę od 6 do $20 \mathrm{~cm}$. Wszystkie one były wbite na ogół mniej lub więcej ukośnie w dno jeziora. W wykopie I układały się one wyraźnie w postaci dwóch ciągów wielopalowych wiązek filarowych, tworzących konstrukcję nośną, charakterystyczną dla mostów palowo-jarzmowych. W wykopie I, na szerokości do $6 \mathrm{~m}$, zadokumentowano wiązkę składającą się z trzech do czterech pali. W wykopie II, o szerokości około I8 m, nie stwierdzono wyraźnie dwurzędowego układu reliktów palowych mostu, natomiast zadokumentowano tu gęstą koncentrację pali prawie na całej eksplorowanej powierzchni wykopu. 
Duża koncentracja przestrzenna pali w tym wykopie wskazuje niewątpliwie na większą liczbę kolejnych inwestycji remontowych mostu, przeprowadzanych w tym samym miejscu jego lokalizacji lub obok mostu już istniejącego. Trzeba mieć na uwadze, iż w szerokim pasie przesmyku jeziornego, gdzie przebiegało podwodne koryto rzeki Schwentine, na głębokości około ı m, znacznie szerszy musiał być tutaj również rozstaw pali w poszczególnych wiązkach filarowych. Nie można też wykluczyć, iż most w brzegowej partii wyspy, przy domniemanej bramie grodowej, zbudowany był w typie szerszej niż most platformy, przy której cumowały też łodzie, utrzymujące kontakt z kilkunastoma osiedlami i użytkami rolniczo-pasterskimi zlokalizowanymi na półwyspach, wyspach i przy brzegach jeziora Großer Plöner See i połączonego z nim Bischofssee. Dla codziennej komunikacji głównym traktem pozostawał jednak most, gdyż na ogół małe łodzie jednopienne nie zawsze mogły zaspokoić niezbędne potrzeby transportowe dla gospodarczego funkcjonowania wyspowej społeczności.

Dla odtworzenia rytmu konstrukcyjnego odkrytego mostu niezbędna była chronologiczno-przestrzenna sortymentacja pali metodą analiz dendrochronologicznych. Łącznie wycięto 79 pali dębowych z zachowaną korą, z których udało się uzyskać daty roczne ich wycięcia tylko w 27 przypadkach. Daty te wskazywały, iż wielokrotne prace inwestycyjno-remontowe prowadzono na moście w Olsborgu w latach 975-I096. Najstarsza roczna data (rok 975) wskazuje nie tylko budowę pierwszego mostu, ale i zapewne początek osadnictwa na tej wyspie. Dalsze daty wycinek drewna budowlanego przypadają na lata 994, 995, I005, I008, I0II, IOI2, IOI3, IO25 i ostatni raz na rok I089 (Wilke 2009: 135; por. ryc. 8). Nie można też wykluczyć znacznie większej liczby kolejnych inwestycji tego typu, gdyż pozytywne datowania dotyczą tylko ı \% zbioru odkrytych pali. Daty wycinek drewna wskazują na dość dużą częstotliwość niezbęd nych prac budowlano-remontowych mostu czy też tylko jego fragmentów.

\section{Analiza morfometryczna i typologiczna broni drzewcowej z Olsborga na tle analogicznych znalezisk z terenu Słowiańszczyzny północno-zachodniej}

W trakcie archeologicznej eksploracji podwodnej na badanej części zalegania reliktów mostu oraz poza nimi, w środkowej partii przesmyku jeziornego, dokonano odkrycia 56 zabytków - fragmentów ceramiki, różnych narzędzi i ozdób, oporządzenia jeździeckiego i elementów uzbrojenia, w tym zespołu broni drzewcowej - Is grotów włóczni i oszczepów, które zostaną poddane analizie morfometryczno-typologicznej w tym opracowaniu. Zespół ten mieści się w świetle badań dendrochronologicznych w przedziale chronologicznym od końca $\mathrm{x}$ w. prawie do końca XI w. Zważywszy jednak na informacje źródeł pisanych o niemieckim 
podboju Wagrii i zniszczenie grodu w Olsborgu w latach I138-I139, można domniemywać, iż również w tych latach mogły być utracone w rejonie mostu niektóre z odkrytych tam egzemplarzy broni drzewcowej.

W zespole broni drzewcowej z Olsborga można wydzielić na podstawie ich oceny morfometrycznej cztery grupy różnych typów grotów, związanych głównie z ich militarnym wykorzystaniem na polu walki, a niekiedy $\mathrm{i} w$ innych okolicznościach życia codziennego ich ówczesnych użytkowników.

\section{Typ A}

Do pierwszej grupy grotów zaliczono pięć egzemplarzy, określając ją jako typ A-Olsborg (dalej: A-I, 2, 3, 4, 5). Wszystkie groty tego typu to okazy o długich i stosunkowo wąskich liściach kształtu deltoidalnego. Górną część liścia stanowił wydłużony ostroboczny trójkąt. Dolną, znacznie krótszą część grotów, stanowiły wąskie tulejki rozszerzające się ku wylotowi (por. ryc. 4). Ten typ grotów charakteryzuje się dużym zróżnicowaniem długości, mieszczącym się w przedziale od $22,2 \mathrm{~cm}$ (typ A-4) do 57,0 cm (typ A-I). Podobnie duże zróżnicowanie zaobserwowano w wadze poszczególnych grotów o przeciętnej, dość dużej wadze $236 \mathrm{~g}$, wagowo skrajne egzemplarze mieszczą się w przedziale od $92 \mathrm{~g}$ (typ A-4) do $574 \mathrm{~g}$ (typ A-I). Liście grotów osiągały maksymalną szerokość od 2,I cm (typ A-4) do $3,8 \mathrm{~cm}$ (typ A-I i A-5). Wszystkie liście grotów były w przekroju dwustożkowane, o maksymalnej grubości I,O cm (typ A-I), w pozostałych liście grotów posiadały grubości $0,7 \mathrm{~cm}$. W jednym przypadku grań liścia grotu miała w dolnej części nieznaczną półowalną wypukłość, podkreśloną dwoma wzdłużnymi rowkami (Typ A-I). Wszystkie groty tej grupy posiadały okrągłe zakończenie wylotu tulejki o średnicy od I,8 do 2,7 cm, tylko na jednym z grotów zaobserwowano, iż w środkowej części tulejki ma ona nieregularnie ośmioboczny kształt (typ A-5). W jednym z grotów w dolnej części tulejki widoczna była okrągła główka nitu mocującego drzewce (typ A-5), a w kolejnym przypadku zaobserwowano ozdobne główki dwu miedzianych nitów, wbitych ukośnie w drzewce (typ A-4). Sytuacja ta była dobrze widoczna na zdjęciu rentgenowskim tej partii grotu. Na liściu jednego z grotów można było zaobserwować nikłe ślady damascenowania (A-5), w jednym przypadku na liściu obu płazów widoczne były biegnące równolegle do ostrza rowki (A-4).

Wszystkie egzemplarze broni drzewcowej tej grupy, mające analogię na ziemiach polskich, zaliczyć można do grotów typu III, według klasyfikacji opracowanej przez A. Nadolskiego (1954). Mają one również wyraźne nawiązania stylistyczne do grotów typu M i K według typologii J. Petersena (1919), występując w różnych miejscach na obszarze kultury wikińskiej.

Na obszarze Polski nie było do niedawna zbyt dużych kolekcji tego typu militariów, tylko po kilka egzemplarzy wymienia się w ostatnich opracowaniach 


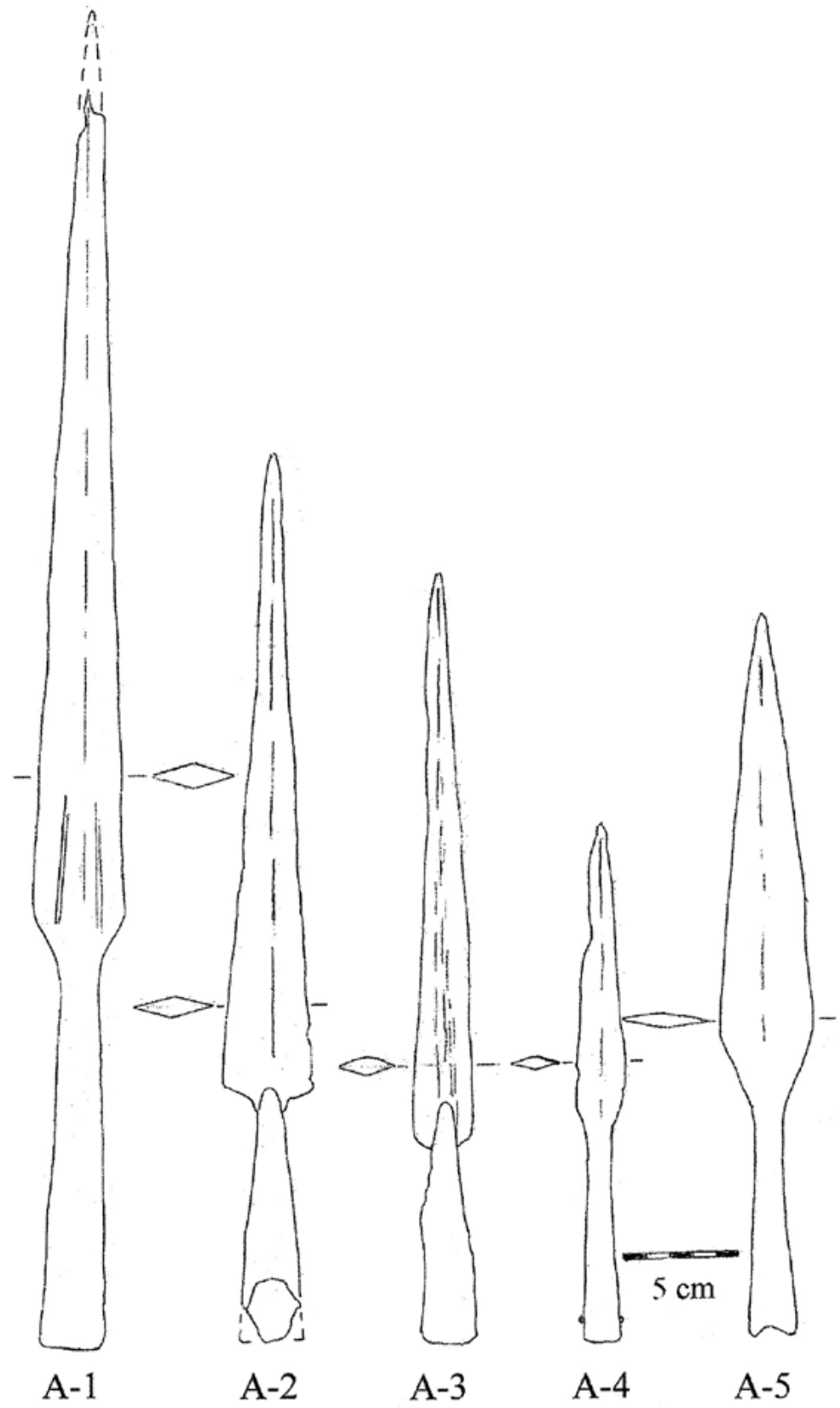

Ryc. 4. Groty grupy typologicznej Olsborg A (rys. G. Wilke). 
grotów z terenu Pomorza Zachodniego (Świątkiewicz 2002: 4I). Frekwencję tego typu grotów na terenie Polski zmieniły odkrycia dokonane w toni jeziora lednickiego, na reliktach dwóch mostów przy rezydencji pierwszych Piastów na Lednicy. Kolekcja liczy bowiem 2I egzemplarzy, ze zbioru odkrytych tam 58 egzemplarzy broni drzewcowej. Stanowi to jak dotąd jedną z największych grup tego typu militariów na terenie Słowiańszczyzny, pochodzącą z jednej miejscowości (Wilke 20I 4: 95-134; 2018: 54-62; Sankiewicz 20I8: 186-206; katalog nr 16-36). Warto tu tylko zasygnalizować, iż wśród nich trzy groty były bogato zdobione techniką powierzchniową, przy pomocy tauszowania srebrem i złotem, a kolejnych I2, z różnorodnymi elementami zdobienia liści czy tulejek grotów, poddawane różnym zabiegom technicznym. Groty te uznawane są za elementy kultury skandynawskiej (Wilke 2020: 55-60). Wszystkie groty tej grupy zostały utracone w wodzie, w walkach na obu mostach, w czasie napadu księcia czeskiego Brzetysława na królewską rezydencję w I038 lub I039 r. Z tego względu groty, jak i inne militaria odkryte w czasie podwodnej eksploracji mostów, stanowią zespół broni drzewcowej o wyjątkowo precyzyjnym datowaniu.

Dość duża kolekcja interesujących nas grotów - 22 egzemplarze - odkryta została na terenie Słowiańszczyzny północno-zachodniej, na obszarze zasiedlonym przez słowiańskich Wieletów. Wydobyto je z czterech rzek tego regionu, tj. Peene wraz z grodem w Demmin ( 9 egzemplarzy), z rzeki Reknitz ( 5 egzemplarzy), Tollense ( 2 egzemplarze) i Trebel ( 6 egzemplarzy). Zostały one odkryte na prawie podobnej liczbie stanowisk archeologicznych zlokalizowanych na brzegach wspomnianych rzek (Anders 2013: 248-252; patrz katalog grotów). Wszystkie one technologicznie reprezentują dość proste wytwory kowalskie, które parametrami wielkościowymi i wagowymi podobne są do okazów broni drzewcowej z Olsborga. Na ogół są one datowane w szerokich ramach czasowych od $\mathrm{x}$ do XII w., często w oparciu o znajdywane wraz z nimi inne zabytki o lepszych wyznacznikach chronologicznych. Na żadnym z tych grotów, nawiązujących formą do zabytków skandynawskich typu M i K według Petersena, nie stwierdzono bowiem śladów damascenowania ani tauszowania kolorowymi metalami, co wskazywałoby, iż mogą być one zabytkami wytworzonymi na terenie Skandynawii, jak również krajów wschodniego wybrzeża Morza Bałtyckiego. Tylko na kilku egzemplarzach stwierdzono dookolne, wielokrawędziowe zgrubienia tulejki na styku z liściem, a w jednym przypadku na sześciobocznej tulejce znajdowały się wzdłużne rowki, wskazujące być może na ich skandynawską proweniencję.

Obok grupy grotów wydobytych z koryt wymienionych wyżej rzek, analogiczne groty znane są również z innych terenów zasiedlonych przez Wieletów. Kilka egzemplarzy odkryto w zespole II grotów włóczni wydobytych na reliktach mostu w Behren-Lübchin, gdzie datowane są w szerokich ramach chronologicznych od XI do XIII w. Z dużym prawdopodobieństwem zostały one utracone w czasie 
szturmu poprzez most do bramy grodowej przez wojska Waldemara I duńskiego W II7I r. (Schuldt 1965: 125).

W kolejnym zespole sześciu analogicznych militariów pochodzących z badań wykopaliskowych na grodzisku w Oldenburgu/Starigardzie, naczelnym grodzie plemienia Wagrów, dwa groty odpowiadają stylistycznie typowi A-Olsborg i datowane są tam w szerokich ramach chronologicznych od pierwszej połowy XII do XIII w. (Kempke 1991: 15-17; taf. 4, 2 i 3).

Podobne okazy znane są również z Haithabu (Hedeby), usytuowanego u nasady Półwyspu Jutlandzkiego, na granicy saksońsko-wikińskiej, na północ od Olsborga. Ośrodek ten powstał już w VIII w., przeżywał okres największej świetności od IX do połowy XI w. Wśród odkrytych 33 grotów, w części całkowicie, a w części tylko zachowanych fragmentarycznie, co utrudnia określenie ich morfometrycznego obrazu, wydzielono iz typów, o dużym zróżnicowaniu wagowo-wielkościowym. Typ 9 (nr 5788) i typ Io (nr 5813) nawiązują do typu A-Olsborg (Westphalen 2002: 23I; taf. 88,I i 88,2). Warto dodać, iż grot typu io miał damascenowany liść, widoczny w postaci falistych linii biegnących przy krawędzi liścia. Obydwa te groty datowane są na XI w.

\section{Typ B}

Do następnej grupy grotów zaliczono pięć dalszych grotów, określając je jako typ B-Olsborg (dalej: B-I, 2, 3, 4, 5). Groty tego typu to okazy dość krępe, o liściu podwójnie daszkowatym, określanym w literaturze kształtu lancetowatego lub wydłużonego serca, w dolnej partii bardzo wyraźnie rozszerzającym się i biegnącym łukowato do tulejki (por. ryc. 5). Liść jednego z grotów posiada lekko faliste ostrze (B-5). Jeżeli chodzi o długość, to mieszczą się one w większości w przedziale średniej wielkości od 16,4 do $18,8 \mathrm{~cm}$, tylko w jednym przypadku grot posiadał prawdopodobnie długość $27,3 \mathrm{~cm}$, gdyż zakończenie ostrza zostało ułamane na 23,0 cm długości grotu (B-I). Liście grotów posiadają dość duże zróżnicowanie szerokości, oscylującej w granicach od I,6 cm (B-2) do 3,6 cm (B-I). Wszystkie liście grotów posiadają dwustożkowaty przekrój, osiągając maksymalną grubość od $0,5 \mathrm{~cm}(\mathrm{~B}-\mathrm{I}, \mathrm{B}-2, \mathrm{~B}-5)$ do $0,6 \mathrm{~cm}$ (B-3, B-4). Jeżeli chodzi o wagę, to groty tej grupy mają bardzo zróżnicowane wartości, od $50 \mathrm{~g}$ (B-2, $38 \mathrm{~g}$ i B-5, $47 \mathrm{~g})$ do $100 \mathrm{~g}$ (B-4,

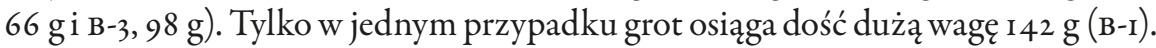
U czterech grotów zakończenia wylotów tulejek posiadają kształt okrągły, ich średnice oscylują w przedziale od I,5 cm (B-5) do maksymalnie 2,4 cm (B-I). Tulejki pozostałych dwóch grotów posiadają średnice $2,0 \mathrm{~cm}$. Na jednej tulejce tuż przy wylocie tkwiła główka nitu, po drugim nicie znajdował się już tylko otwór (B-3). Tylko jeden z grotów tej grupy posiadał ośmioboczny kształt wylotu tulejki o przekroju 2,0 cm, ze śladami otworów po dwóch nitach (B-4). 


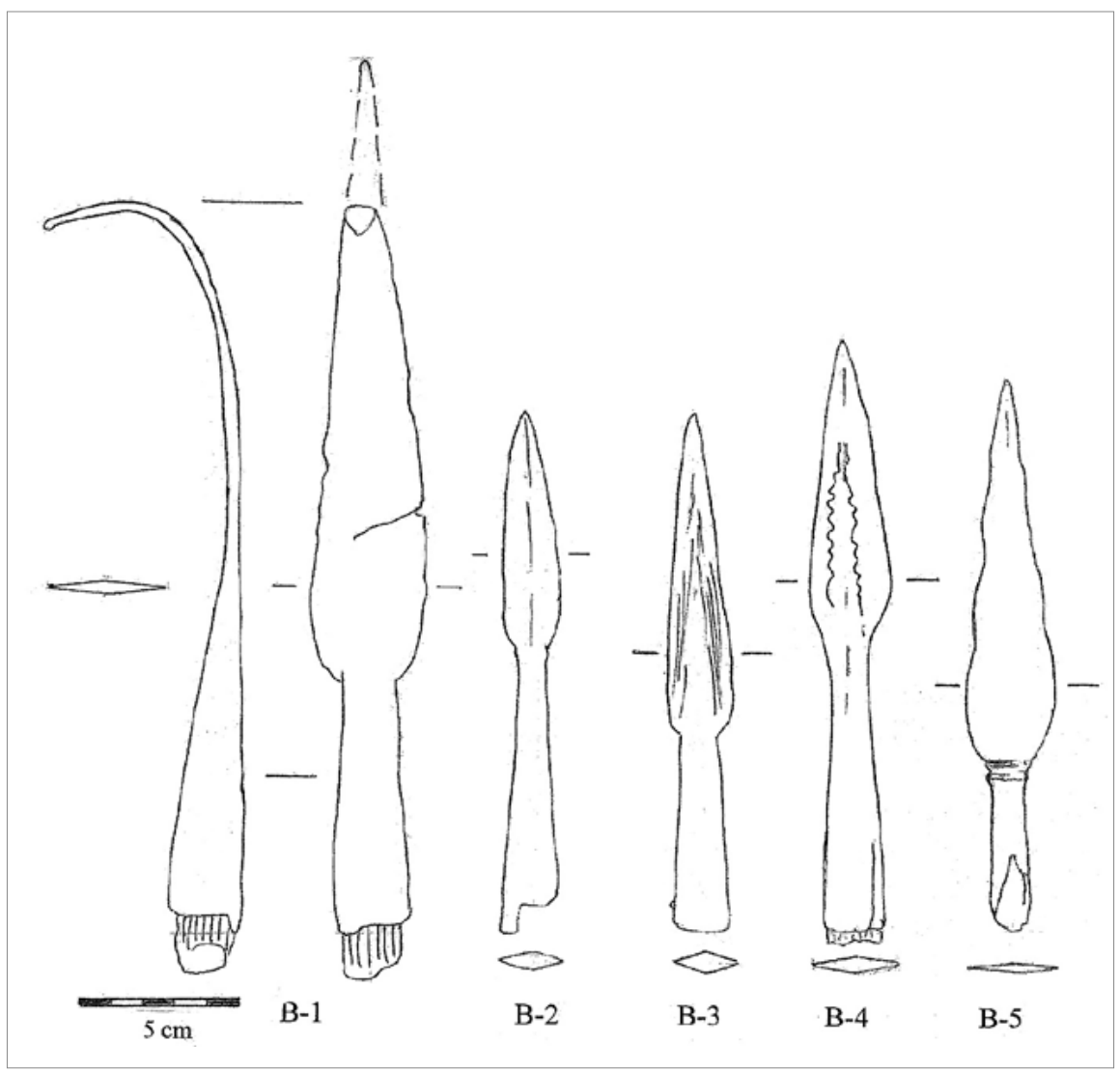

Ryc.5. Groty grupy typologicznej Olsborg в (rys. G. Wilke).

Na liściu jednego z grotów włóczni zaobserwowano trzy niewielkie piktogramy pracowni kowalskiej lub też znaki identyfikacyjne użytkowania tej broni drzewcowej (B-5). Stwierdzono również, iż tulejka tego grotu była wyraźnie oddzielona od liścia kątowym podcięciem i dwoma dookolnymi wałeczkami. Na liściu kolejnego grotu, na jego obu płazach, widoczne było zdobienie w formie pasemka rowków biegnących równolegle do ostrza (B-3). Rowki te zaczynały się u nasady liścia grotu, zbiegając się w kierunku końcówki ostrza. Obserwacja rentgenowska wykazała, iż grot ten posiadał damascenowany rdzeń z nałożonym na niego ostrzem. Zdjęcie rentgenowskie wykazało również, iż na liściu jednego z kolejnych grotów widoczny był bardzo wyraźnie ornament „wilczych zębów”, biegnący pojedynczymi falistymi pasmami, równolegle do krawędzi ostrza grotu (B-4). Warto tu wspomnieć, iż ze względu na niewielkie wagowe i wielkościowe parametry czterech grotów tej grupy, można przypuszczać, że nie stanowiły one 
grotów włóczni, służących do zadawania pchnięć z niewielkiej odległości, głównie przez ruchliwych, lekko zbrojnych jeźdźców, lecz groty oszczepów służących do miotania, głównie przez pieszych wojowników, z pewnego dystansu (B-2, B-3, B-4, B-5). Tylko jeden z grotów tej grupy, znacznie większy i dwu-trzykrotnie cięższy, stanowił element włóczni (B-I). Nie można jednak zapominać, iż na polu walki, w zależności od sytuacji, oba te rodzaje broni miały uniwersalne przeznaczenie, polegające na zadaniu śmierci przeciwnikowi.

Analogiczne okazy należące do dość rzadko występujących na ziemiach polskich, zostały określone w typologii A. Nadolskiego jako groty typu IV (1954). Dawniej większość z nich pochodziła z XI-wiecznych cmentarzysk kujawskich. Również sporadycznie znane są one z terenu Pomorza Zachodniego (Świątkiewicz 2002: 42). Tylko dwa egzemplarze odkryte zostały również w toni jeziora na reliktach mostów prowadzących do rezydencji pierwszych Piastów na Lednicy (Wilke 20I8: 62; Sankiewicz 20I8: 24I-242).

W rzekach na obszarze północno-wschodnich Niemiec z dużego zbioru broni drzewcowej, liczącego I 40 egzemplarzy grotów, wydobyto tylko siedem okazów tego typu, które pochodziły z rzeki Tollense ( 2 egzemplarze), rejonu grodu w Demmin i rzeki Peene (4 egzemplarze) oraz z Reknitz (I egzemplarz). Wszystkie one, podobnie jak i okazy z Olsborga, należały do grotów o stosunkowo niewielkiej wadze i rozmiarach, w większości o długości do $20 \mathrm{~cm}$, tylko dwa posiadały długość dochodzącą do $30 \mathrm{~cm}$ (Anders 2013: 248-252; patrz katalog grotów). Chronologicznie mieszczą się one wszystkie $\mathrm{w}$ przedziale od $\mathrm{x}$ do XII w.

Dwa groty typu B-Olsborg znane są również z wikińskiego Haithabu (Hedeby) i określone tam jako typ ir (nr 5803) i typ iz (nr 5790). Obydwa należą również do okazów niewielkich o długości 15,5 cm i 18,5 cm (Westphalen 2002: 231; taf. 88,3 i taf. 88,6). Na podstawie innych analogii z sąsiednich terenów słowiańskich ich chronologię z dużą ostrożnością określa się na okres od XI do początków XII w.

Również dwa analogiczne groty typu A-Olsborg znane są w zespole broni drzewcowej pochodzącejz badań wykopaliskowych na grodzisku w Oldenburgu/Starigardzie (Kempke 1991: 15-18; ryc. 4, 4 i 4, 5), nawiązujące wyraźnie do typu A według klasyfikacji Petersena (1919), a nie do typu M według tego badacza. Obydwa groty to również egzemplarze niewielkich rozmiarów, o długości 13,9 cm (kat. nr 6) i rekonstruowanej długości około $14 \mathrm{~cm}$ ( $\mathrm{kat} . \mathrm{nr} 7$ ). Na podstawie relacji stratygraficznych z badań grodziska obydwa groty datować można na początek XI w. do początku XII w.

Dość sporadyczne występowanie analizowanych grotów typu B-Olsborg na terytorium kultury słowiańskiej, grotów o niewielkich parametrach wielkościowych, jak i wagowych, było być może podyktowane ich małą przydatnością militarną na polu walki, w odróżnieniu od większych i cięższych grotów innych typów, stanowiących elementy włóczni. Być może groty Typu B-Olsborg stanowiły element uzbrojenia oszczepu, broni przeznaczonej do miotania. 


\section{Typ C}

Do kolejnej wydzielonej grupy grotów zaliczono cztery egzemplarze, określając je jako typ C-Olsborg (dalej: C-I, 2, 3, 4). Groty tego typu to okazy o bardzo długim i wąskim lancetowatym liściu, określanym również w literaturze przedmiotu kształtem liścia wierzby. Liście, na ogół o długości dwukrotnie większej od długości tulejek, u dołu nieznacznie rozszerzają się w stosunku do tulejki (por. ryc. 6). Długość grotów oscyluje w granicach od $30 \mathrm{~cm}$ (C-4) do $47 \mathrm{~cm}$ (C-I), przy średniej, dość dużej wartości ich długości $32,4 \mathrm{~cm}$. W analizowanej grupie liście grotów osiągały szerokość od 2,4 cm (C-3) do maksymalnej szerokość 3,2 cm (C-2 i C-4). Wszystkie liście grotów były w przekroju dwustożkowate, o grubości od o,6 cm (C-I, C-2 i C-4) do maksymalnie o,8 cm (C-3). Jeżeli chodzi o wagę, to w trzech przypadkach całkowicie zachowanych grotów nieznacznie tylko przekraczała ona 200 g (C-I, C-2 i C-4). Wszystkie okrągłe zakończenia wylotów tulejki posiadały średnice oscylujące w przedziale od 2,I cm (C-2) do 2,8 cm (C-4). W końcowej partii jednej tulejki zaobserwowano pozostałość dwóch główek nitów mocujących drzewce włóczni (C-3), w kolejnych przypadkach dwa otwory po nitach (C-2) oraz jeden zachowany nit i otwór po nicie (C-I). Interesująco prezentuje się tulejka jednego z grotów, posiadająca na całej długości ornament w postaci pionowych, wielopasmowych żłobkowanych linii falistych (C-2). Na liściach dwóch grotów widoczne były na zdjęciach rentgenowskich zabiegi damascenowania (C-I i C-2).

Analogiczne groty zostały określone w polskiej literaturze przedmiotu jako typ v według typologii A. Nadolskiego (1954). Groty te, jak wskazuje katalog 70 egzemplarzy analizowanych przez tego autora, należały do najczęściej odkrywanych na stanowiskach archeologicznych na ziemiach polskich, nie wyróżniając się jednak jakąś szczególną cechą, a mieszczące się w tym typie egzemplarze stanowiły formy o bardzo zróżnicowanej wielkości i wadze. O dużej frekwencji tego typu świadczą też nowe opracowania militariów tego typu z terenu Pomorza Zachodniego, gdzie reprezentowane były w liczbie 36 egzemplarzy, datowanych w dość szerokich ramach chronologicznych od viII aż do końca XIII w. (Świątkiewicz 2002: 42 i nn.).

O dość powszechnym występowaniu grotów typu C-Olsborg na terenie ziem polskich świadczy też odkrycie ich dużej kolekcji na reliktach mostów przy piastowskiej rezydencji Ostrowa Lednickiego. Z toni jeziora lednickiego wydoby to 22 egzemplarze tego typu militariów (Wilke 2018: 62-65; Sankiewicz 2018: 186-207, nr kat. 39-60). Prawie wszystkie one należały do grotów o średniej długości, w granicach od 20 do $30 \mathrm{~cm}$ (I okazów) i większej długości, w granicach od 30 do $40 \mathrm{~cm}$ (9 okazów). Wśród tych grotów znalazł się również najdłuższy jak dotąd grot o długości $73 \mathrm{~cm}$. Podobne relacje można zaobserwować na grotach z Olsborga. Odmienne są tylko parametry wagowe, groty Ostrowa Lednickiego są bowiem zdecydowanie cięższe, nieco masywniejsze, sześć grotów przekracza wagę 300 g, 


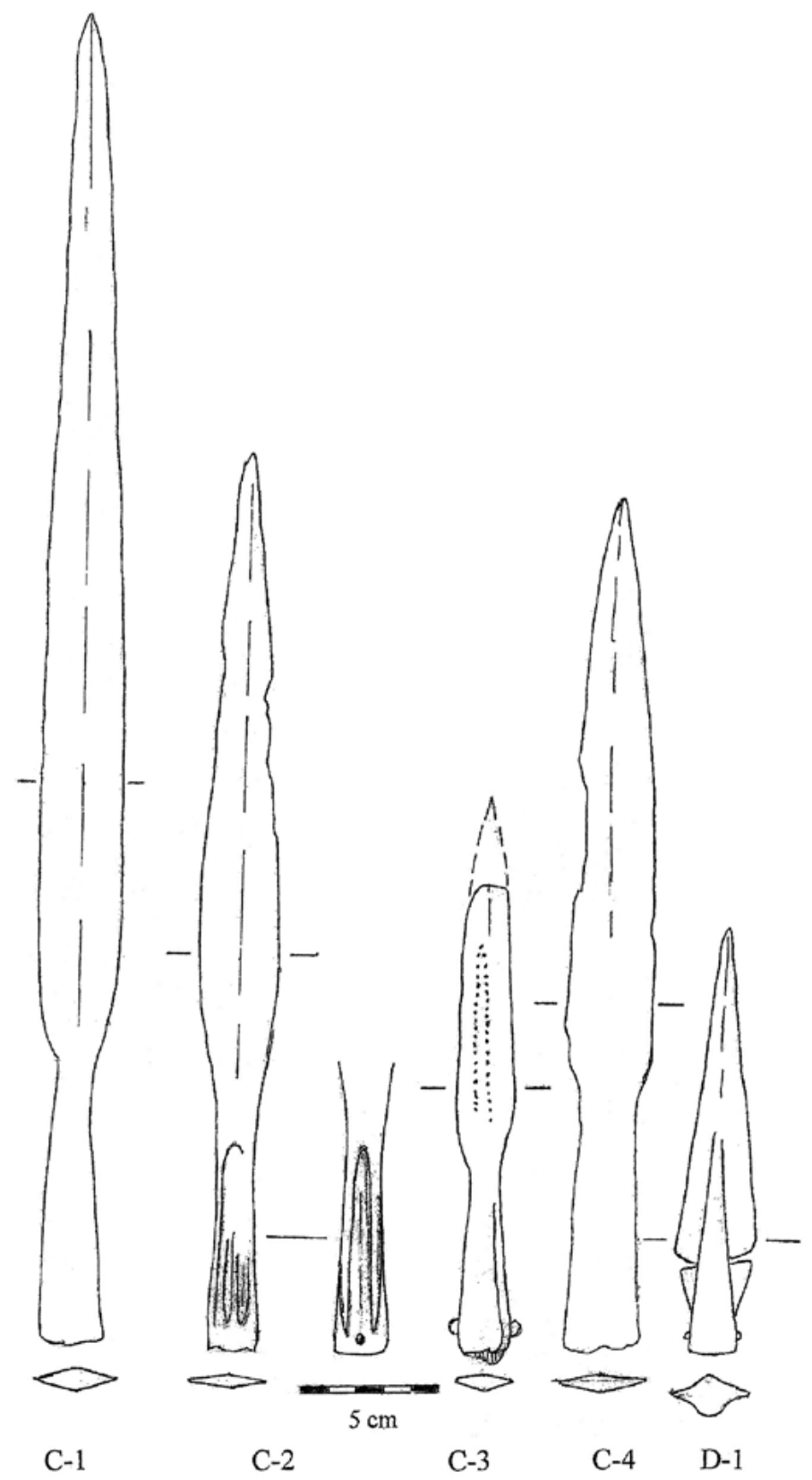

Ryc.6. Groty grupy typologicznej Olsborg C i D (rys. G. Wilke). 
a jeden $\mathrm{z}$ nich nawet wagę $680 \mathrm{~g}$ (nr kat. 40), co stawia go w rzędzie najcięższego jak dotąd okazu na obszarze ziem słowiańskich. Warto też zasygnalizować, iż na I 4 grotach tego typu odkrytych na Ostrowie Lednickim aż I 4 okazów miało różnego rodzaju zdobienia i ornamentację powierzchniową, co pozwala pewną ich część wiązać z kręgiem wytwórczości wikińskiej ze Skandynawii i wschodnich wybrzeży Morza Bałtyckiego oraz najbliższym tym wybrzeżom Gotlandii. Warto tylko wspomnieć, iż na tej wyspie, wśród odkrytych prawie 600 grotów broni drzewcowej, znanych jest około 275 egzemplarzy nawiązujących do typu c-Olsborg, które pojawiają się tam już od początków IX w. Ta liczba świadczy też, iż był to najbardziej popularny rodzaj grotów na terenie Skandynawii (Thunmark-Nylén 2006: 301-302).

Koncentrując się na znaleziskach akwatycznych grotów, warto wspomnieć, iż ten typ grotu wystąpił w największej liczbie w kompleksowych badaniach archeologicznych prowadzonych w wodach śródlądowych Pomorza i Wielkopolski. W latach 2006-20I5 odkryto tam na siedmiu stanowiskach i3 analogicznych grotów, w Lubniewicach, Chycinie, Krępsku, Nętnie, Bninie, Izdebnie i Długiem (Chudziak i in. 2011; 2016).

Analogiczne groty typu C-Olsborg należały do najbardziej masowo odkrywanych na terenie północno-wschodnich Niemiec, gdzie z czterech rzek tego regionu pochodzi w sumie 56 grotów, co świadczy, iż również na tym terenie zasiedlonym przez Wieletów były to najbardziej powszechne w użyciu militaria broni drzewcowej. Z Demmin i rzeki Peene pochodzą 22 egzemplarze, z rzeki Tollense - Io egzemplarzy oraz z Trebel - I7 egzemplarzy i Reknitz 7 (Anders 2013: 248-252; patrz katalog grotów). Wszystkie groty są na ogół datowane na okres od x do XII w. Analiza morfometrycza wskazuje, iż wszystkie one cechuje duże zróżnicowanie wielkościowe, jak i zapewne wagowe. Długość ich mieści się bowiem w przedziale od $13,4 \mathrm{~cm}$ do $52,0 \mathrm{~cm}$. Zły stan zachowania wielu z nich i pewne ubytki materiałowe nie pozwalają na prześledzenie dokładnych relacji wagowych, które zostały pominięte w katalogu. W dużej kolekcji tych grotów tylko na jednym okazie zaobserwowano, iż lancetowaty liść miał z obu stron grani tauszowanie srebrem, co pozwala jego pochodzenie wiązać z dużym prawdopodobieństwem z wytwórczością warsztatów wikińskich.

Analogiczne groty znane są też z badań na niektórych grodziskach tego obszaru, m.in. z Drense, Kreis Prenzlau (Schmidt 1989: 49 i nn.) oraz z Vipperow, Kreis Röbel (Hollnagel, Schoknecht 1956: 134). Obydwa odkryte tam groty datowane są na przełom XI i XII w.

Podobny okaz do typu C-Olsborg znany jest również z wikińskiego Haithabu (Hedeby), wśród I3 wydzielonych tam typów (Westphalen 2002: 23I, por. taf. 87,3). Okaz ten o długości 32,4 cm, oznaczony jako typ 7 Haithabu, nawiązujący do skandynawskiego typu A według Petersena (I919), może być datowany na X w. 
Typ D

Do tej grupy grotów zaliczono tylko jeden egzemplarz, określając go dalej jako Typ D-Olsborg (dalej: D-I). Grot ten, o zachowanej długości i 4,8 cm (pierwotnie ca. $15,8 \mathrm{~cm}$ ), posiada liść kształtu deltoidalnego o długości II, $8 \mathrm{~cm}$ (por. ryc. 6). Lisić grotu zgrzany jest techniką kowalską na rdzeniu o okrągłym przekroju, o długości $8,0 \mathrm{~cm}$, stanowiącym w końcowej partii tulejkę o średnicy wylotu $20 \mathrm{~mm}$, do umocowania drzewca. Przy wierzchołku rdzenia liść grotu posiada dwustożkowaty przekrój o maksymalnej grubości $8 \mathrm{~mm}$. U podstawy liść szeroki na $26 \mathrm{~mm}$ oparty jest na tulejce mającej tu średnicę $14 \mathrm{~mm}$. U wylotu tulejka również okrągła, osiągająca średnicę $20 \mathrm{~mm}$. Poza podstawą deltoidalnego liścia, $3 \mathrm{~mm}$ poniżej, znajdują się na tulejce trójkątne, czy zbliżane do kształtów półtrapezowatych skrzydełka, o długości Is $\mathrm{mm}$ i szerokości grzbietu od $5 \mathrm{~mm}$ (strona lewa) do $7 \mathrm{~mm}$ (strona prawa). Były one zgrzane z tulejką techniką kowalską. U podstawy tulejki znajdują się główki dwóch ukośnie wbitych nitów mocujących drzewce, widoczne wyraźnie na zdjęciu rentgenowskim. Ze względu na niewielką wagę - $73 \mathrm{~g}$ i niewielką długość, egzemplarz ten można również z dużym prawdopodobieństwem zaliczyć do grotu oszczepu. Opisany okaz stanowi odmianę szerokiej rodziny grotów ze skrzydełkami. W odróżnieniu jednak od egzemplarza z Olsborga, groty tej grupy były zdecydowanie większe i cięższe, i te używane były zarówno na polu walki, jak i na polowaniach, głównie na „grubego zwierza”, tj. niedźwiedzia i dzika. Stąd też niektóre groty tego typu dochodziły do wagi I,5 $\mathrm{kg}$ (Westphal 2002: 265).

Interesującym materiałem porównawczym dla długości grotów tego typu może być duża seria tego typu egzemplarzy z terenu z północno-wschodnich Niemiec, gdzie wśród 33 egzemplarzy, 2 I grotów miało duże rozmiary, mieszczące się w granicach od 40 do 61,5 cm (Westphal 2002: 255, por. tabelę 3). Podobnym przykładem może być też duża seria 35 grotów tego typu z Holandii, gdzie aż 29 egzemplarzy miało rozmiary przekraczające $40 \mathrm{~cm}$, Io egzemplarzy osiągało długość ponad $50 \mathrm{~cm}$, a najdłuższy okaz osiągał długość prawie $55 \mathrm{~cm}$ (Ypey 1982: 250 i nn, patrz katalog).

Zarówno o ich uniwersalnym używaniu na polu walki, jak i na polowaniach informują nas licznie średniowieczne kroniki czy ilustrowane ewangeliarze (Wilke 20I8: 66-67). Przyjmuje się generalnie, iż dłuższe poprzeczki, jak i krótsze skrzydełka, pozwalały na łatwiejsze odparcie broni przeciwnika, jak i ograniczenie zbyt gębokiej penetracji w ugodzonym ciele przeciwnika lub zwierzęcia, a po zadaniu ciosu umożliwienie szybkiego wyciągnięcia włóczni i zadanie kolejnego ciosu. Grot z Olsborga był prawdopodobnie elementem oszczepu, używanym na polu walki głównie do miotania, bez bezpośredniego kontaktu z przeciwnikiem czy zwierzęciem na polowaniu. Grot ten, stanowiący element lekkiej włóczni, mógł spełniać również inne funkcje, o czym pośrednio informują nas zarówno źródła 
pisane oraz ikonograficzne, jak i ryciny na monetach czy pieczęciach heraldycznych. Broń drzewcowa była bowiem również nośnikiem ważnych treści ideologicznych jako broń insygnialna i heraldyczna, służąc m.in. do przytwierdzania proporców w kształcie małych banderek czy też w kształcie smoków, jak i przytwierdzania różnych innych znaków. Szerzej ten temat wspomniany był już w pracy o broni drzewcowej z Ostrowa Lednickiego (Wilke 2018: 39-40). W szczelinie pomiędzy podstawą liścia i skrzydełkami łatwiej było bowiem mocować do rdzenia grotu rzemieniem lub powrozem różnego rodzaju akcesoria przestrzenne niż na drzewcu czy grocie bez jakichkolwiek elementów poprzecznych.

\section{Uwagi końcowe}

Przyjmuje się w formie roboczej tezy, iż militaria broni drzewcowej odkryte w toni jeziora Grosser Plöner See, na reliktach mostu przy wyspie grodowej Olsborg w Plön, znanej ze źródeł pisanych jako Plune, są śladem działań militarnych przy zdobywaniu wyspy, związanych z wydarzeniami politycznymi XI i XII w. Wydarzenia te to najpierw walki pomiędzy książętami słowiańskimi, a później władcami niemieckimi, w ramach prowadzonej przez nich długiej chrystianizacji oraz kolonizacji ziem słowiańskiej Wagrii. W odkrytej kolekcji Is grotów włóczni, a zapewne i w części grotów oszczepów, wydzielono na podstawie analizy morfometryczno-typologicznej cztery typy, określane dalej jako typ A-Olsborg, typ B-Olsborg, typ C-Olsborg i typ D-Olsborg (por. ryc. 4-6). Stwierdzono dalej, iż $\mathrm{w}$ trzech pierwszych grupach rozkład ilościowy zamykał się w liczbie pięciu (xz) i liczbie czterech (xI) egzemplarzy. Spojrzenie jednak na ich frekwencję na terenie Słowiańszczyzny północno-zachodniej, jak i basenu Morza Bałtyckiego, pozwalało stwierdzić, iż liczbowo dominującymi typami były analogiczne okazy z grupy typu A-Olsborg i C-Olsborg. Zostały one określone według typologii grotów dla ziem polskich opracowanej przez A. Nadolskiego (1954) typem III i V, natomiast według typologii grotów wikińskich opracowanych przez J. Petersena (1919) typem M i K oraz typem E i G. Obie te typologie, jedna licząca już przeszło ıoo lat, a druga prawie 50 lat, mimo prób weryfikacji i budowania nowych podtypów, są do dzisiaj podstawowymi metrometrycznymi wzorcami grotów dla Słowiańszczyzny północno-zachodniej, jak i krajów basenu Morza Bałtyckiego i konsekwentnie wykorzystywane dalej przez badaczy polskich, jak i niemieckich zajmujących się bronią drzewcową. Nie można oczywiście pomijać licznych nowych opracowań, głównie dla Skandynawii i wschodnich wybrzeży Morza Bałtyckiego (Wilke 20ı8: 47-50). Mimo nowych prób badaczy łódzkiego ośrodka studiów bronioznawczych dla Pomorza Zachodniego (Świątkiewicz 2002) i Małopolski (Strzyż 2006) oraz olbrzymiego przyrostu bazy źródłowej, brak jest nadal kompleksowego opracowania typologii grotów dla całej Słowiańszczyzny północno-zachodniej. Dobrym 
punktem wyjścia mogłaby tu być kolekcja I 40 egzemplarzy broni drzewcowej wydobytych z czterech rzek północno-wschodnich Niemiec (Anders 2013: 248-252) czy kolekcja 56 grotów wydobytych z toni jeziora z reliktów mostów przy rezydencji pierwszych Piastów na Lednicy (Sankiewicz 2018: 147-215; Wilke 2018: 33-87).

Na grotach z Olsborga, mimo podobieństw stylistycznych do skandynawskich okazów, tylko w czterech przypadkach stwierdzono ślady damascenowia (grot A-4; grot B-4 oraz groty C-r i C-2), co wskazywałoby, iż mogły one być zabytkami wytworzonymi na terenie Skandynawii, a może i również krajów wschodniego wybrzeża Morza Bałtyckiego. W starszej literaturze przyjmowano, iż groty te były na terenie Skandynawii importami z terenu cesarstwa frankońskiego (Arbman 1937: 232 i nn.), w późniejszej literaturze pojawiły się wnioski, iż z terenu cesarstwa została również przeniesiona technika ich wykonania, stanowiąc już później typowy produkt miejscowy (Selirand 1975: 184).

To na tych terenach stwierdzono bowiem nie tylko liczne rejony występowania rudy żelaza i miejsca ich obróbki, ale i poświadczono intensywne uprawianie rzemiosła kowalskiego, zadokumentowane odkryciami kilkuset grobów kowali z bogatymi inwentarzami narzędzi kowalskich. W wyniku szczegółowej analizy morfometrycznej i technologicznej udało się również w wielu miejscach na tym terenie stwierdzić liczbę kowali produkujących określone serie grotów, co poświadczałoby ich daleko posuniętą specjalizację i dość szeroką dystrybucję tych elementów uzbrojenia. Szerzej na ten temat mówiono już wcześniej w literaturze przedmiotu (Wilke 2018: 6I-62). Pozostałe groty z Olsborga, jak i odkryte na całym obszarze Słowiańszczyzny północno-zachodniej, a wykonane w stosunkowo prostej technologii kowalskiej, bez damascenowania, bez tauszowania kolorowymi metalami oraz bez dodatkowych zdobień, głównie na tulejkach grotów, odkute zostały prawdopodobnie w miejscowych warsztatach kowalskich. Stanowiły one nie tylko swobodne naśladownictwo obcych form grotów, ale i przejaw dużej standaryzacji broni drzewcowej.

Dla wytrawnego kowala, nawet obecnie, nie było bowiem większego problemu wyprodukowanie całych serii grotów bełtów do kuszy tylko na podstawie prezentacji oryginalnych zabytków z późnośredniowiecznych Słoszew, które kowal widział pierwszy raz. W przeprowadzonym eksperymencie kowal odtworzył również technologię wykonywania różnych odmian tych grotów (Kola, Wilke 1975). Interesujące nas militaria - groty broni drzewcowej, będące na wyposażeniu nie tylko wojsk książąt słowiańskich w ich międzyplemiennych wojnach domowych, ale i wojsk sąsiednich nacji, zostały utracone w licznych kampaniach wojennych na tym terenie, $w$ tym zakresie prawdopodobnie również w Olsborgu. Początek konfliktów zbrojnych wiązać można z wojną trzydziestoletnią prowadzoną w latach 772-804 przez cesarza Karola Wielkiego z Sasami, poddanymi Franków, którzy nacierali systematycznie w kierunku prowincji nadreńskich. Działania 
wojsk frankońskich na wschodzie doprowadziły do spotkania ze Słowianami zamieszkującymi rozległe tereny Połabszczyzny, między dolną Łabą i wybrzeżem Morza Bałtyckiego. W walkach przeciw Sasom udzielali pomocy Obodrzyce. To wtedy mogli oni pierwszy raz wejść w kontakt z obcymi im militariami frankońskimi i saskimi, a ze względu na północne, bliskie sąsiedztwo, również z bronią wikińską. Za datę zakończenia szerszych kontaktów militarnych na tym terenie można przyjąć rok II 47, kiedy odbyła się niemiecka krucjata połabska - zbrojna wyprawa wojenna, skierowana głównie przeciw Obodrzycom i Lucicom, dowodzona przez księcia saskiego Henryka Lwa i przełożonego Marchii Północnej Albrechta Niedzwiedzia. Wszystkie mniejsze i większe potyczki i zbrojne konflikty na tym terenie omówiono szerzej w ostatniej monografii grotów lednickich (Wilke 2018: 43-44).

\section{Bibliografia}

\section{Źródła}

Adam von Bremen = Adam von Bremen, Hamburgische Kirchengeschichte, red. B. Schmeidler, Hannover-Leipzig 1917 (Scriptores Rerum Germanicarum in usum scholarum ex Monumentis Germaniae Historicis Separatim, Editi 2).

Helmold = Helmolda Kronika Stowian, tłum. wg J. Matuszewski, Warszawa 1974.

\section{Opracowania}

Anders J. (2007), Die slawenzeitlichen Flussfunde Nordostdeutschland als Hinweise auf Verkehrswege, „Siedlungsforschnung. Archäologie - Geschichte - Geographie”, 25, s. 319-328.

Anders J. (2013), Früh-und hochmittelalterliche Flussfunde in Norddeutschland. Das Material aus Peene, Recknitz, Tollense und Trebel und seine siedlungsgeschichtliche Einbindung, Verlag Dr. Rudolf Habelt GmbH, Bonn (Studien zur Archäologie Europas, 19).

Arbman H. (1937), Schweden und das Karolingische Reich. Studien zu den Handelsverbindungen des 9. Jahrbunderts, Wahlström \& Widstrand, Stockholm.

Bleile R. (2011), Zur Funktion slawischer Inselsiedlungen im Io. Jahrhundert, [w:] F. Birmann, T. Kersting, A. Klammt (red.), Der Wandel um 1ooo. Beiträge der Sektion zur Slawischen Frühgeschichte der I8. Jahrestagung des Mittel-und Ostdeutschen Verbandes für Altertumsforschung in Greifswald, 23. bis 27. März 2009, Langenweissbach Beier \& Beran, Langenweissbach (Beiträge zur Ur- und Frühgeschichte Mitteleuropas, 60), s. 63-83.

Bleile R., Müller U., Dörfler W., Huber F., Lüth P., Reese I., Wieckowska M.(2010), Funktionen von Inseln in der limnischen Kulturlandschaft Nordeutschland - Vorbericht zu einem interdisziplinären Forschungsprojekt an der Christian-Albrechts-Universität $z u$ Kiel, „Nachrichtenblatt Arbeitskreis Unterwasserarchäologie”, 16, s. 25-29. 
Chudziak W., Kaźmierczak R., Niegowski J.(2011), Podwodne dziedzictwo archeologiczne Polski. Katalog stanowisk (2006-2009), Wydawnictwo Fundacji Amicus Universitatis Nicolai Copernici; Wydawnictwo Uniwersytetu Mikołaja Kopernika, Toruń.

Chudziak W., Kaźmierczak R., Niegowski J. (2016), Podwodne dziedzictwo archeologiczne Polski. Katalog stanowisk (20II-20I5), Wydawnictwo Fundacji Amicus Universitatis Nicolai Copernici; Wydawnictwo Uniwersytetu Mikołaja Kopernika, Toruń.

Dörfler W. (2009), Seespiegelschwankungen des Großen Plöner Sees im Lichte alter und neuer Daten, [w:] U. Müller, S. Kleingärtner, F. Huber (red.), Zwischen Nord-und Ostsee 1997-2007. Zehn Jahre Arbeitsgruppe für maritime und limnische Archäologie (AMLA) in Schleswig-Holstein, Verlag Dr. Rudolf Habelt, Bonn, s. I43-I55.

Fraesdorf D. (2005), Der barbarische Norden. Vorstellungen und Fremdheitskategorien bei Rimbert, Thietmar von Merseburg, Adam von Bremen und Helmold von Bosau, De Gruyter, Berlin (Orbis mediaevalis. Vorstellungswelten des Mittelalters, 5), https://doi.org/I0.1524/978305004845I

Hollnagel A., Schoknecht U. (1956), Die Burgwallinsel bei Vipperow, Kries Röbel, „Bodendenkmalpflege in Mecklenburg”, 1954, S. I2I-I42.

Kempke T. (1991), Starigard/Oldenburg. Hauptburg der Slawen in Wagrien. III. Die Waffen des 8.-I3. Jahrhunderts, Wachholtz, Neumünster (Offa-Bücher, 73).

Kempke T. (1992), Slawen in Ostholstein. Ausgrabungen in Bosau am Plöner See, [w:] Der Vergangenheit auf der Spur. Archäologische Siedlungsforschung in Schleswig-Holstein, Wachholtz, Neumünster, s. I4I-165.

Kola A., Wilke G. (1975), Produkcja grotów bettów do kuszy w średniowieczu w świetle wspótczesnych prób eksperymentalnych, „Acta Universitatis Nicolai Copernici. Archeologia", 5, S. 16I-I8I.

Müller U. (20II), Olsborg - eine Inselsiedlung um das Jahr Iooo, [w:] F. Birmann, T. Kersting, A. Klammt (red.), Der Wandel um 1ooo: Beiträge der Sektion zur Slawischen Frühgeschichte der I8. Jahrestagung des Mittel-und Ostdeutschen Verbandes für Altertumsforschung in Greifswald, 23. bis 27. März 2009, Langenweissbach Beier \& Beran, Langenweissbach (Beiträge zur Ur- und Frühgeschichte Mitteleuropas, 60), s. 85-96.

Müller-Wille M. (1999), Opferkulte der Germanen und Slawen, Wissenschaftliche Buchgesellschaft, Sttutgart (Archäologie in Deutschland. Sonderheft).

Nadolski A. (1954), Studia nad uzbrojeniem polskim wX, XI i XII wieku, Łódzkie Towarzystwo Naukowe, Łódź.

Petersen J.(1919), De norske vikingesverd. En typologisk-kronologisk studie over vikingetidens vaaben, J. Dybwad, Kristiania.

Sankiewicz P. (2018), Katalog broni drzewcowej, [w:] P. Sankiewicz, A.M. Wyrwa (red.), Broń drzewcowa i uzbrojenie ochronne z Ostrowa Lednickiego, Giecza i Grzybowa, Muzeum Pierwszych Piastów na Lednicy, Lednica (Biblioteka Studiów Lednickich, I), S. $147-215$.

Schmidt V. (1989), Drense. Ein Hauptburg der Ukrane, Deutscher Verlag der Wissenschaften, Berlin (Beiträge Ur- und Frühgeschichte, Bezirk Rostock, Schwerin und Neubrandenburg, 22).

Schuldt E. (1965), Behren-Lübchin. Eine spätslawische Burganlage in Mecklenburg, Akademie-Verlag, Berlin. 
Selirand J. (1975), Estnische Gruppe der nordeuropäischen Lanzenspitzen mit damasziertem Blatt, „Toimetised Eesti Nsv Teadute Akad. 24. Ühiskonnatea dused”, s. $17 \mathrm{I}-187$.

Strzyż P. (2006), Uzbrojenie we wczesnośredniowiecznej Matopolsce, Łódzkie Towarzystwo Naukowe, Łódź (Acta Archaeologica Lodziensia, 52).

Świątkiewicz P. (2002), Uzbrojenie wczesnośredniowieczne z Pomorza Zachodniego, Łódzkie Towarzystwo Naukowe, Łódź (Acta Archaeologica Lodziensia, 48).

Thunmark-Nylén L. (2006), Die Wikingerzeit Gotlands, Bd. III. I-2, Text, Almqvist \& Wiksell International, Stockholm.

Westphal H.(2002), Franken oder Sachsen? Untersuchungen an frühmittelalterlichen Waffen, Isensee, Oldenburg (Studien zur Sachsenforschung, I4).

Westphalen P. (2002), Die Eisenfunde von Haithabu, Karl Wachholtz, Neumünster.

Wilke G. (1998), Relikty osadnictwa stowiańskiego w Jeziorze Ptońskim Wielkim (Großer Plöner See) $w$ Niemczech $w$ świetle archeologicznych badań podwodnych, [w:] H. Kóćka-Krenz, W. Łosiński (red.), Kraje stowiańskie w wiekach średnich. Profanum i Sacrum. Ksiega jubileuszowa Z. Hilczer-Kurnatowskiej, Wydawnictwo Poznańskiego Towarzystwa Przyjaciół Nauk, Poznań, s. 262-272.

Wilke G. (2005), Helmolds von Bosau „pons longissimus”. Archäologische Unterwasserforschungen bei der Brückenanlagen neben der slawischen und frübdeutschen Burg Olsborg im Grossen Plöner See (Norddeutschland), „Folia Praehistorica Posnaniensia”, 13/I4, s. 279-292, https://doi.org/10.14746/fpp.2005.13.20

Wilke G. (2006), Próba interpretacji podwodnych odkryć militariów przy rezydencji pierwszych Piastów na Ostrowie Lednickim, [w:] M. Dworaczyk, A.B. Kowalska, S. Moździoch, M. Rębkowski (red.), Świat Stowian wczesnego średniowiecza, Wydawnictwo Instytutu Archeologii i Etnologii PAN, Szczecin-Wrocław, s. 443-455.

Wilke G. (2009), Archäologische Unterwasserforschungen an der spätslawischen Brücke der Insel Olsborg, Kreis Plön, [w:] U. Müller, S. Kleingärtner, F. Huber (red.), Zwischen Nord und Ostsee 1997-2007. Zehn Jahre Arbeitsgruppe für maritime und limnische Archäologie (AMLA) in Schleswig-Holstein, Verlag Dr. Rudolf Habelt, Bonn, s. I29-I 42 .

Wilke G. (201I), Najstarsze mosty zachodniostowiańskie z międzyrzecza Łaby i Odry (VIII-X/XI wiek), „Acta Universitatis Nicolai Copernici. Archeologia”, 31, s. 57-I25.

Wilke G. (2014), Militaria - broń drzewcowa. Analiza formalno-typologiczna,

[w:] A. Kola, G. Wilke (red.), Wczesnośredniowieczne mosty przy Ostrowie Lednickim, t. II, Mosty traktu poznańskiego (Wyniki archeologicznych badań podwodnych prowadzonych w latach 1986-2003), Towarzystwo Autorów i Wydawców Prac Naukowych Universitas, Kraków, s. 95-I34.

Wilke G. (2018), Groty broni drzewcowej z Ostrowa Lednickiego, [w:] P. Sankiewicz, A.M. Wyrwa (red.), Broń drzewcowa i uzbrojenie ochronne z Ostrowa Lednickiego, Giecza i Grzybowa, Muzeum Pierwszych Piastów na Lednicy, Lednica (Biblioteka Studiów Lednickich, I), s. 33-87.

Ypey J. (1982), Flügellanzen in niederländischen Sammlungen, [w:] G. Krause (red.), Vorund Frühgeschichte des unteren Niederreins. R. Stampfuss zum Gedächtnis, R. Habelt, Bonn, s. 24I-267. 


\section{Summary}

Großer Plöner See is located between Kiel and Lübeck, in the central part of the socalled Holstein Switzerland. The island hillfort of Plune (Olsborg) appears for the first time in the source information of the chronicler Adam Bremen in 1070. At the Olsborg hillfort island is spearheads and javelins were discovered excavated from a small area of investigated bridge debris. This assemblage falls, in the light of dendrochronological research, between the late $\mathrm{I}^{\text {th }}$ and late $\mathrm{II}^{\text {th }}$ centuries. However, taking into account the information from written sources about the German conquest of Vagria and the destruction of the hillfort in $\mathrm{II}_{3} 8-\mathrm{II}_{4} 2$, it can be presumed that also in those years some of the pole arm discovered there may have been lost in the area of the bridge.

Keywords: spearheads, Bridges, Early Middle Ages, Großer Plöner See, northern Germany 